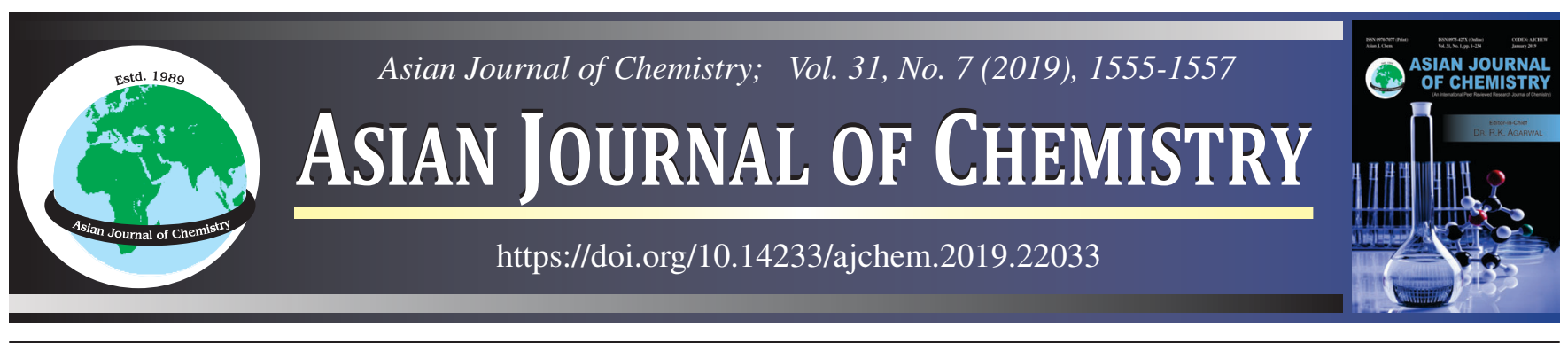

\title{
Ultrasonication Assisted Bligh and Dyer Method for Extraction of Lipids from Green Algae
}

\author{
R. Ghosh ${ }^{1, *}$, R. Makam ${ }^{2}$, V. Krishnamurthy ${ }^{2}$, R.R. Siva Kiran ${ }^{3}$, Bijay Krishna Chaudhuri ${ }^{4}$ and M.C. Saurav Shastry ${ }^{3}$
}

${ }^{1}$ Department of Chemical Engineering, Calcutta Institute of Technology, Uluberia-711316, India

${ }^{2}$ Department of Biotechnology, PES Univesity, Banashankari 3rd Stage, Bangalore-560085, India

${ }^{3}$ Department of Chemical Engineering, M.S. Ramaiah Institute of Technology, Bangalore-560054, India

${ }^{4}$ Centre For Rural \& Cryogenic Technologies, Jadavpur University, Kolkata-700032, India

*Corresponding author: E-mail: rajesh_laltu@yahoo.co.in

Received: 27 February 2019;

Accepted: 26 March 2019;

Published online: 21 May 2019;

AJC-19413

We have modified the original Bligh and Dyer method by introducing ultrasonication for enhancing the lipid extraction from green algae and compared with Soxhlet extractor. The Bligh and Dyer method coupled with ultrasonication increased the lipid extraction from green algae, Oedogonium sp. by up to $3.95 \%$, Botyrococcus braunii KUTZING NIES 2199 up to $8.5 \%$, Cladophora sp. up to $4.5 \%$. Therefore, ultrasonication assisted Bligh and Dyer method might be an important development for the removal of lipids from green algal biomass. 1

Keywords: Lipid extraction, Bligh and Dyer method, Green algae, Botyrococcus braunii, Oedogonium sp., Cladophora sp.

\section{INTRODUCTION}

The rapid increase in the demand for fuel energy has encouraged the scientific community worldwide to search for more reliable energy sources other than the conventional fuels. The biofuels hold a promising future to sustain the equilibrium between demand and supply of the energy. The competition of the first generation biofuels with the livestock feed gave rise to second generation of biofuels, wherein there was no need for compromising on the side of food resources [1-4]. The yield and efficiency of the second generation biofuels was required to increase to meet the demand. This gave rise to the third generation of biofuels, where both the problems were attempted to solve. The primary stock of the third generation is the microalgae. The growth of algae is not subjected to specificity of place or time of the year. This unique property is an added advantage for algae based fuels for continuous production throughout the years. Although algae provide us with drastically high efficiency of yields and no binding on time and place of growth [5-7], competitive commercialization of algae biofuels is yet to be realized. Fuels derived from algae cost much more than its conventional counterparts. The main hurdle in its commercial viability is biological challenges [8-10]. Harnessing energy from algae implies benefitting from the biological properties of algae. The research to overcome problems involves amplifying the algal properties, which are harnessed in the form of fuels. Biomass is considered as one of the best renewable source of energy which not only helps as an alternative source but also contributes to removal of carbon dioxide from atmosphere. Biodiesel produced from biomass is one such alternative fuel, which is obtained by the transesterification of triglycerides present in biomass. It is non-toxic and biodegradable and does not pose any health hazards. Lipid extraction using suitable and efficient solvents is the first primary step for increasing production of biodiesel from biomass. Among various biomass sources, microalgae usually have higher photosynthetic efficiency. Elumalai et al. [11] reported that algae is considered as a superior source for biodiesel production when compared with plant sources. All algae primarily comprise of carbohydrates, proteins, fats and nucleic acid. While the percentages differs based on the type of algae. Dried biomass of some type of algae comprises up to $40 \%$ of fatty acids [12]. These fatty acids contain triglycerides which can thereby use for conversion into biodiesel.

Oedogonium is a filamentous green algae which can be identified by a distinctive rings at the apical ends of certain cells. It lives in quiet, fresh water and can be used to extract biodiesel. Zhang et al. [13] reported that Oedogonium sp. has about $45.38 \%$ of lipids by dry weight. Other green algae's like

This is an open access journal, and articles are distributed under the terms of the Creative Commons Attribution-NonCommercial-ShareAlike 4.0 (CC BY-NC-SA 4.0) International License which allows readers to freely read, download, copy, distribute, print, search, or link to the full texts of its articles and to use them for any other lawful non-commercial purpose as long as the original source is duly acknowledged. 
Botyrococcus brauni KUTZING NIES 2199 and Cladophora sp. has more than 30-40 \% of lipids [14] and $40 \%$ [15] of lipids by dry weight, respectively.

Extraction techniques like the Soxhlet method and Bligh and Dyer method are commonly used for lipid extractions from biomass. The Soxhlet method for lipid extraction is done using hexane, petroleum ether or ethyl acetate. The disadvantages of Soxhlet method include its long duration and wastage of large amount of solvents. Disposal of solvents is not only expensive but also causes additional threat to the environment.

The Bligh and Dyer method is considered as one of the best method for polar lipid extraction. It has wide applications in environmental engineering for analyzing lipid content of the samples [9-7]. The method mainly consists of extraction of fats using polar solvent mixtures (chloroform, methanol and water (1:2:0.8)). After extraction, the chloroform layer was removed and evaporated for collection of residual fats. Since the introduction of this method, many scientists have used it in various fields for extraction of polar ad neutral lipids $[11,12]$. Ranjan et al. [16] has compared Bligh and Dryer method, Soxhlet method and ultrasonicaation assisted Bligh and Dryer method for removal of lipids from Scenedesmus sp. Upto $8 \mathrm{~g}$ of lipids can be extracted from $100 \mathrm{~g}$ of dry biomass of Scenedesmus sp. [17]. Botyrococcus brauni can give $30 \mathrm{~g}$ of lipids per $100 \mathrm{~g}$ of dry biomass [18].

In present study, the original Bligh and Dyer method has been modified by introducing three changes including the change in the composition of solvents, increasing the mechanical homogenization time and introducing ultrasonication for lipid extraction for Botyrococcus brauni, Oedogonium sp. and Cladophora sp. The study also involves comparing the results with conventional Soxhlet method and original Bligh and Dyer method [10-12].

\section{EXPERIMENTAL}

Hill and Machlis media for algal growth (viz. $\mathrm{CuSO}_{4} \cdot 5 \mathrm{H}_{2} \mathrm{O}$, $\mathrm{Na}_{2} \mathrm{~B}_{4} \mathrm{O}_{7} \cdot 10 \mathrm{H}_{2} \mathrm{O}, \mathrm{CoCl}_{2} \cdot 6 \mathrm{H}_{2} \mathrm{O}, \mathrm{MnCl}_{2} \cdot 4 \mathrm{H}_{2} \mathrm{O}, \mathrm{ZnSO}_{4} \cdot 7 \mathrm{H}_{2} \mathrm{O}, \mathrm{CaCl}_{2}$. $2 \mathrm{H}_{2} \mathrm{OKNO}_{3},\left(\mathrm{NH}_{4}\right)_{6} \mathrm{Mo}_{7} \mathrm{O}_{24} \cdot 4 \mathrm{H}_{2} \mathrm{O}, \mathrm{FeSO}_{4} \cdot 7 \mathrm{H}_{2} \mathrm{O}, \mathrm{N}\left(\mathrm{CH}_{2} \mathrm{COOH}\right)_{3}$, $\mathrm{MgSO}_{4} \cdot 7 \mathrm{H}_{2} \mathrm{O}, \mathrm{KH}_{2} \mathrm{PO}_{4}$ and vitamin $\mathrm{B} 12$ ), chloroform and methanol (Merck, India). Distilled water was used throughout the experiments (Millipore Sigma India).

Maintenance of green algae cultures: Bulk biomass of Oedogonium $\mathrm{Sp}$. and Cladophora $\mathrm{Sp}$. were obtained directly

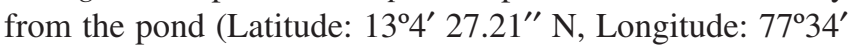
47.7156" E) present in University of Agricultural Sciences, GKVK Campus, Bengaluru, India. The bulk biomass of Oedogonium sp. and Cladophora sp. were dried and kept for storage at $-4{ }^{\circ} \mathrm{C}$ for further experimentation.
Botyrococcus braunii KUTZING NIES 2199 was procured from National Institute for Environmental Studies, Microbial Culture Collection, Tsukuba, Japan. Botyrococcus braunii KUTZING NIES 2199 was maintained in $250 \mathrm{~mL}$ Erlenmeyer flasks. Modified CHU 13 media (Table-1) medium (150 mL) was added to Erlenmeyer flasks and plugged with cotton and incubated at $25^{\circ} \mathrm{C}$. Bulk biomass for lipid extraction was produced using autoclavable polypropylene bags. The light intensity was maintained at 1200 lux and $\mathrm{pH}$ at 7.5 for the modified CHU 13 media inside polypropylene bags. The concentration of Botyrococcus braunii KUTZING NIES 2199 in terms of number density was found using UV-visible spectrophotometer at $686 \mathrm{~nm}$. Botyrococcus braunii KUTZING NIES 2199 was harvested after 28 to 30 days from the polypropylene bags once it reaches maximum absorbance.

Harvesting of biomass: Biomass was harvested by centrifugation and drying. The medium containing algal biomass was taken in polyethylene centrifuge tubes and centrifuged for $10 \mathrm{~min}$ at $6000 \mathrm{rpm}$ (Remi Centrifuse, India). After centrifugation, the resultant supernatant was discarded. The biomass present at the bottom of centrifugal tubes was kept at $45^{\circ} \mathrm{C}$ for 4 to 5 days in a hot air oven. The dried biomass of microalgae was powdered using mortar and pestle before using it for lipid extraction [16].

Lipid extraction procedure: The dried biomass of three green algae (Botyrococcus braunii KUTZING NIES 2199, Oedogonium sp. and Cladophora sp.) was treated by three methods for extraction of lipids as described below:

Bligh and Dyer method: The Bligh and Dyer method was proposed in 1959 for extraction of lipids from fish muscle. Algae biomass of $2.5 \mathrm{~g}$ was homogenized in a blender for 2 min with $20 \mathrm{~mL}$ of chloroform and $40 \mathrm{~mL}$ of methanol. To this mixture again $20 \mathrm{~mL}$ of chloroform was added and continued blending for $30 \mathrm{~s}$. To this mixture, $20 \mathrm{~mL}$ of distilled water was added and again blended for $30 \mathrm{~s}$. The final solution was filtered using Whatman no. 1 filter paper. The solution was kept in a separating funnel for $20 \mathrm{~min}$. The residual biomass along with filter paper was blended with $20 \mathrm{~mL}$ chloroform. The mixture is filtered and rinsed with $10 \mathrm{~mL}$ chloroform. Both chloroform solutions were added and evaporated for extraction of lipids. The final weight of lipid was measured.

Ultrasonication assisted Bligh and Dyer method: Algal biomass weighing $2.5 \mathrm{~g}$ on dry basis was taken for ultrasonication assisted Bligh and Dyer method. Methanol ( $40 \mathrm{~mL})$ and chloroform $(40 \mathrm{~mL})$ was added to algal biomass and blended for $10 \mathrm{~min}$. To this mixture, additional $20 \mathrm{~mL}$ chloroform and $20 \mathrm{~mL}$ water was added and homogenized for $10 \mathrm{~min}$ and ultrasonicated for another $10 \mathrm{~min}$. The Erlenmeyer flask was covered with a cap to stop chloroform from evaporating and cooled in

\begin{tabular}{|c|c|c|c|}
\hline \multicolumn{4}{|c|}{$\begin{array}{c}\text { TABLE-1 } \\
\text { MODIFIED CHU } 13 \text { MEDIA (NIES, JAPAN) }\end{array}$} \\
\hline Compounds & Grams & Compounds & Grams \\
\hline Potassium nitrate $\left(\mathrm{KNO}_{3}\right)$ & 240 & Manganese(II) chloride tetrahydrate $\left(\mathrm{MnCl}_{2} 4 \mathrm{H}_{2} \mathrm{O}\right)$ & 2.172 \\
\hline Dipotassium phosphate $\left(\mathrm{K}_{2} \mathrm{HPO}_{4}\right)$ & 48 & Zinc sulfate heptahydrate $\left(\mathrm{ZnSO}_{4} \cdot 7 \mathrm{H}_{2} \mathrm{O}\right)$ & 0.264 \\
\hline Calcium chloride dehydrate $\left(\mathrm{CaCl}_{2} \cdot 2 \mathrm{H}_{2} \mathrm{O}\right)$ & 64.2 & Copper(II) sulfate pentahydrate $\left(\mathrm{CuSO}_{4} \cdot 5 \mathrm{H}_{2} \mathrm{O}\right)$ & 0.096 \\
\hline Magnesium sulfate heptahydrate $\left(\mathrm{MgSO}_{4} \cdot 7 \mathrm{H}_{2} \mathrm{O}\right)$ & 120 & $0.072 \mathrm{~N} \mathrm{H}_{2} \mathrm{SO}_{4}$ (sulfuric acid) & 1 drop \\
\hline Ferric citrate $\left(\mathrm{C}_{6} \mathrm{H}_{5} \mathrm{FeO}_{7}\right)$ & 12 & Cobalt(II) chloride $\left(\mathrm{CoCl}_{2}\right)$ & 0.012 \\
\hline Citric acid $\left(\mathrm{C}_{6} \mathrm{H}_{8} \mathrm{O}_{7}\right)$ & 60 & Boric acid $\left(\mathrm{H}_{3} \mathrm{BO}_{3}\right)$ & 3.432 \\
\hline
\end{tabular}


TABLE-2

EXTRACTION OF LIPIDS FROM THREE GREEN ALGAE USING VARIOUS METHODS

\begin{tabular}{lccc}
\hline \multirow{2}{*}{ Method } & \multicolumn{2}{c}{ Green algae (grams lipid per 2 g of algae biomass) } \\
\cline { 2 - 4 } & Botyrococcus braunii KUTZING NIES 2199 & Oedogonium sp. & Cladophora sp. \\
\hline Bligh and Dryer method & 0.218 & 0.072 & 0.315 \\
Ultrasonication Assisted Bligh and Dyer method & 0.322 & 0.083 & 0.482 \\
Soxhlet method & 0.168 & 0.056 & 0.218 \\
\hline
\end{tabular}

water bath with ice [19]. The final solution was filtered using Whatman no. 1 filter paper. The residues were treated similar to the original Bligh and Dyer method [20].

Soxhlet method: The soxhlet flasks were dried in oven at $100{ }^{\circ} \mathrm{C}$ for $1 \mathrm{~h}$ and cooled for $30 \mathrm{~min}$ inside desiccators. The algal biomass weighing $2.5 \mathrm{~g}$ was taken in Soxhlet extraction tube. Approximately $100 \mathrm{~mL}$ of chloroform was added to Soxhlet flask and the sample was extracted for $24 \mathrm{~h}$. The condensation rate was about 2 to 3 drops per second. The chloroform was distilled and the flask was dried in a hot air oven for $2 \mathrm{~h}$ at 105 ${ }^{\circ} \mathrm{C}$. The flask was again cooled and weighted for final lipid concentration.

\section{RESULTS AND DISCUSSION}

Extraction of lipids from green algae (Botyrococcus braunii KUTZING NIES 2199, Oedogonium sp. and Cladophora sp.): The three methods (Bligh and dryer method, ultrasonication assisted Bligh and Dryer method and Soxhlet method) were used for lipid extraction using three green algae (Botyrococcus braunii KUTZING NIES 2199, Oedogonium sp. and Cladophora sp.). It is quite evident that considerable improvement in the lipid extraction was observed in case of ultrasonication assisted mediated Bligh and dryer method when compared with original Bligh and Dryer method and Soxhlet method. It is also observed that more lipids can be easily extracted from Botyrococcus braunii KUTZING NIES 2199 and Cladophora sp. when compared with Oedogonium sp. Morphologically, Oedogonium sp. and the alga cells are hard to break when compared with Botyrococcus Braunii and Cladophora sp. About $47 \%$ increase in the lipid content was observed for ultrasonication assisted Bligh and Dryer method in case of Botyrococcus braunii KUTZING NIES 2199 and $15 \%$ increase was observed for Oedogonium sp. and $53 \%$ increase was observed for Cladophora sp. when compared with original Bligh and Dryer method. Soxhlet method produced poor results (Table-2). Thus, ultrasonication assisted Bligh and Dryer method proved to be best when compared with original Bligh and Dryer method and Soxhlet method.

\section{CONFLICT OF INTEREST}

The authors declare that there is no conflict of interests regarding the publication of this article.

\section{REFERENCES}

1. A.S. Hossain, A. Salleh, A.N. Boyce, P. Chowdhury and M. Naqiuddin, Am. J. Biochem. Biotechnol., 4, 250 (2008); https://doi.org/10.3844/ajbbsp.2008.250.254.

2. A.H. Hirani, N. Javed, M. Asif, S.K. Basu and A. Kumar, eds.: A. Kumar, S. Ogita and Y.Y. Yau, A Review on First- and Second-Generation Biofuel Productions, In: Biofuels: Greenhouse Gas Mitigation and Global Warming, Springer: New Delhi (2018).

3. S.N. Naik, V.V. Goud, P.K. Rout and A.K. Dalai, Renew. Sustain. Energy Rev., 14, 578 (2010); https://doi.org/10.1016/j.rser.2009.10.003.

4. A.K. Bajhaiya, S.K. Mandotra, M.R. Suseela, K. Toppo and S. Ranade, Asian J. Exp. Biol. Sci., 1, 728 (2010).

5. M.P. Abishek, J. Patel and A.P. Rajan, Biotechnol. Res. Int., 2014, Article ID 272814 (2014); https://doi.org/10.1155/2014/272814.

6. G. Khola and B. Ghazala, Pak. J. Bot., 44, 379 (2011).

7. M. Gavrilescu and Y. Chisti, Biotechnol. Adv., 23, 471 (2005); https://doi.org/10.1016/j.biotechadv.2005.03.004.

8. E.S. Jang, M.Y. Jung and D.B. Min, Comp. Rev. Food Sci., 4, 22 (2005); https://doi.org/10.1111/j.1541-4337.2005.tb00069.x.

9. J. Sheehan, T. Dunahay, J. Benemann and P. Roessler, A Look Back at the U.S. Department of Energy's Aquatic Species Program: Biodiesel from Algae, Close-Out Report, United States Department of Energy July (1998).

10. K. Georgiú and V. Mari, Food Technol. Biotechnol., 39, 175 (2001).

11. S. Elumalai, R. Sakthivel and S.G. Kumar, Curr. Botany, 2, 19 (2011).

12. B. Blagovi, M. Mesari, V. Mari and J. Rup, Croat. Chem. Acta, 78, 479 (2005).

13. W. Zhang, Y. Zhao, B. Cui, H. Wang and T. Liu, Bioresour. Technol., 220, 407 (2016); https://doi.org/10.1016/j.biortech.2016.08.106.

14. P. Metzger and C. Largeau, Appl. Microbiol. Biotechnol., 66, 486 (2005); https://doi.org/10.1007/s00253-004-1779-z.

15. A.M. Illman, A.H. Scragg and S.W. Shales, Enzyme Microb. Technol., 27, 631 (2000); https://doi.org/10.1016/S0141-0229(00)00266-0.

16. A. Ranjan, C. Patil and V.S. Moholkar, Ind. Eng. Chem. Res., 49, 2979 (2010); https://doi.org/10.1021/ie9016557.

17. D.F. Dall'Oglio, L.C. de Sousa, S.A. de Sousa, M.A. Garcia, E.S. Sousa, S.G. de Lima and C.V. de Moura, J. Braz. Chem. Soc., 30, 633 (2019); https://doi.org/10.21577/0103-5053.20180235.

18. K. Yamaguchi, H. Nakano, M. Murakami, S. Konosu, O. Nakayama, M. Kanda and H. Iwamoto, Agric. Biol. Chem., 51, 493 (1987); https://doi.org/10.1271/bbb1961.51.493.

19. E.G. Bligh, and W.J. Dyer, Can. J. Biochem. Physiol., 37, 911 (1959); https://doi.org/10.1139/059-099.

20. L. Xiao, Ph.D. Thesis, Evaluation of Extraction Methods for Recovery of Fatty Acids from Marine Products, University of Bergen (2010). https://sapientia.ualg.pt/handle/10400.1/10737. 